\title{
Integrated Learning Module Development on Department of PGSD Students, Gorontalo State University, Indonesia
}

\author{
Wiwy T. Pulukadang, Hamzah B. Uno, Haris Panal, Keysar Panjaitan
}

\begin{abstract}
The problems in this study are 1) What are the conditions of integrated learning objectives for students majoring in PGSD UNG? 2) How is the quality of integrated learning modules developed for students majoring in PGSD UNG? 3) What is the effectiveness of integrated learning modules for students majoring in PGSD UNG? This study aims to 1) Describe the objective conditions of integrated learning in students majoring in PGSD UNG; 2) Producing quality integrated learning development modules for students majoring in PGSD UNG; and 3) To find the effectiveness of integrated learning modules in students majoring in PGSD UNG.
\end{abstract}

The results showed that the integrated learning objective conditions in the Department of PGSD UNG include the RPS that were designed not in accordance with the appropriate learning structure, good teaching materials were not yet owned by lecturers who were able to take courses, between lecturers supporting integrated learning subjects did not discuss each other as a team teaching so that learning outcomes are not achieved, there are no good teaching materials so students do the assignments correctly and copy and paste assignments and download them from the internet, learning so far without raising problems first to challenge students to be motivated in learning activities, Student less involved in learning, lecturers as learning centers, lack of communication between lecturers and students, students and other students, and lectures are not well structured. After doing research and development in the fourth semester PGSD Department students get better with positive student responses. The quality of integrated learning modules has met the aspects that have been determined. Quality integrated learning modules after being measured based on the characteristics of quality modules there are 5 aspects. The quality of integrated learning modules is also developed based on the input of validators who are media experts, material experts and linguists so that the quality of integrated learning modules becomes better, and the effectiveness of integrated learning modules with 4D stages has fulfilled well-defined aspects.

Keywords—Learning Module, 4 D Development, Integrated Learning.

\section{INTRODUCTION}

Primary School Teacher Education Department at Gorontalo State University, is a member of the Indonesian PGSD Lecturer Association. The PGSD Department of Gorontalo State University has adjusted the curriculum based on joint decisions in the Indonesian PGSD Lecturer Association. In the curriculum structure of the Primary School Teacher Education Department at Gorontalo State University there are courses based on the national curriculum namely Religion, Pancasila, Indonesian Language, English, Sports and Health, Citizenship, Research Methodology, Philosophy of Science, PLP1 and PLP 2, Statistics, and KKS; The University's founding subjects are Cultural Insights, Applied English, Leadership and Entrepreneurship; Faculty's distinguishing courses, namely Introduction to Education, Student Learning Development, Educational Innovation, Educational Psychology, Education for Children with Special Needs, and Educational Sociology; The subjects of the majors are Class Management, Guidance and Counseling in Elementary Schools, Learning Strategies, Media and Learning Resources, Elementary Curriculum Development, Development of Learning Materials, Elementary Indonesian Language Concepts, Basic Mathematics Concepts of Elementary 1 and 2, Basic Concepts of Social Sciences Elementary Schools, Basic Concepts Elementary School 1 and 2 Science, Basic Concepts of Civics Education, Learning Assessment, Integrated Learning, Elementary Indonesian Language Learning, Elementary Social Science Learning, Elementary Mathematics Learning, Elementary Science Learning, Elementary Civics 
Education, SBDP Learning in Elementary School, Teaching Profession, School Based Management, School and Community Relations, Global Perspectives, Regional Cultural Learning, Classroom Action Research, Scientific Writing, Thesis and 12 other elective courses.

Among several subjects majoring in primary school teacher education are integrated learning subjects. Integrated learning courses are taught with the aim of providing provision to prospective teachers of integrated learning classes in elementary schools so that they have the knowledge, experience and skills to plan and implement effective integrated learning. Integrated learning lecture material includes the nature of integrated learning, curriculum analysis, and making Learning Implementation Plans along with integrated Learning Tools in elementary schools. Integrated learning is part of the group of courses of study that must be taught to students because integrated learning courses teach students to develop Learning Implementation Plans and learning tools and are able to teach them in accordance with the national curriculum. Integrated learning subjects with learning outcomes of study program graduates are on the aspect of attitudes towards learning outcomes including 1). Demonstrating an attitude of responsibility for work in their area of expertise independently, 2). To internalize appreciative attitudes and care in the preservation of the environment, arts, and sociocultural values that develop in the community (local wisdom); aspects of knowledge include 3). Mastering conceptual knowledge of study fields in primary schools including Indonesian, Mathematics, Natural Sciences, Social Sciences, Civics, SBdP, and PJOK, 4). Mastering curriculum concepts, approaches, strategies, models, methods, techniques, teaching materials, media and innovative learning resources as classroom teachers in primary schools, 5). Mastering the concepts and techniques of process evaluation and evaluation of learning outcomes in primary schools; aspects of general skills include 6). Able to take appropriate decisions in the context of problem solving in their area of expertise, based on the results of information and data analysis, 7). Able to be responsible for the achievement of group work and to supervise and evaluate the completion of work assigned to workers under their responsibility; aspects of special skills include 8). Applying the concept of the development characteristics of students both the development of students both physical, psychological, and social development through the design and implementation of learning in elementary schools, 9). Applying conceptual knowledge in the field of study in primary schools including Indonesian, Mathematics, Science, Social Sciences, Civics, SBdP, and PJOK through the design and implementation of learning with scientific methods in accordance with academic ethics, 10). Analyzing, reconstructing, and modifying curriculum, approaches, strategies, models, methods, techniques, teaching materials, media and innovative learning resources as classroom teachers in primary schools independently, 11). Designing and carrying out an evaluation of the process and learning outcomes in elementary schools on an ongoing basis.

Every lecturer in the Elementary School Teacher Education Department of Gorontalo State University is required to design learning systematically in order to produce a Semester Learning Plan (RPS) along with learning tools consisting of teaching materials, assignments, assessment instruments, learning media, etc. that can be carried out in the process effective and efficient learning. In accordance with the guidelines for preparing tertiary education curricula in the industrial era 4.0, Semester Learning Plans (RPS) for courses are learning process plans that are prepared for learning activities for one semester to meet the learning achievements of graduates charged to the courses. RPS or other terms, determined and developed by lecturers independently or together in a group of expertise in a field of science and / or technology in a study program.

Researchers as one of the lecturers in the Department of PGSD Gorontalo State University, teach Integrated Learning subjects. Since 2010 researchers have been taking integrated learning courses. But since then lecturers supporting integrated learning courses have not been maximized in carrying out lectures. This happens for many reasons including: 1). The Semester Learning Plan is designed not according to the right learning structure. 2). Lecturers do not have good learning materials. So far, lecturers only give lectures by asking students to find their own source books for integrated learning courses. So many books - books that they buy and download on internet pages that make them have different interpretations in this course. 3). Between lecturers supporting integrated learning courses as team teaching do not discuss each other about the whole learning process, so that if one is unable to attend, the others cannot continue learning in a structured manner that makes students confused so that the learning achievements of the course are not achieved. 4). There are no good teaching materials, so students do not do assignments correctly and copy and paste assignments or just download them from the internet. 5). Learning so far has been carried out without raising problems first to challenge students to be motivated in learning activities, 6). Lecturers without exploring the ability of students to find concepts, lecturers are still using learning as usual which results in a lack of student involvement during the learning 
process. 7). The lecturer as a learning center, students hear or record lessons, and give examples of cases where the discussion is carried out with the help of the lecturer himself, then given exercises that require students to do each of them. 8). Lack of communication among students in discussing the material being studied because the lecturer is lacking in establishing communication between students to solve the problems they face. As well as 9). Lectures on the subject matter of compiling thematic learning tools in integrated learning subjects usually do not teach the practice of systematic learning preparation from the beginning ie students describe the nature of integrated learning, analyze core competencies and basic competencies, map competencies, compile syllabi, compile learning implementation plans, create media, create media teaching materials and assessment. However, it only directly asks students to make lesson plans and teach them in front of the class without clear guidelines, which causes students to be less skilled in developing relevant integrated learning tools.

From the problems above, the researcher wants to develop teaching materials in the form of integrated learning modules that can answer all the problems that exist in integrated learning courses at the Elementary School Teacher Education Department of Gorontalo State University by conducting a research entitled: Development of Integrated Learning Modules in Department Students PGSD Gorontalo State University.

\section{LITERATUR REVIEW}

\section{Module Definition}

The module is one of the learning media in the form of a script or print media that is often used in learning activities. The module is formulated as one complete unit that stands alone, consisting of a series of learning activities arranged to assist learners in achieving learning objectives that are formulated specifically and operationally. Modules are one form of teaching material that is packaged in a whole and systematic way, which contains a set of planned learning experiences and is designed to help students master specific learning goals. Modules contain a minimum of learning objectives, learning material / substance, and evaluation. The module functions as a learning tool that is independent, so students can learn in accordance with their respective speeds. According to the Ministry of National Education (2008: 20), Modules are a set of teaching materials that are presented systematically so that their use can be learned with or without a teacher or facilitator.
Modules optimize learning resources while paying attention to learners to be able to control their learning activities. The role of educators shifts from information providers to learning facilitators by providing various learning resources needed, stimulating learning enthusiasm, providing opportunities to practice their learning outcomes, providing feedback about learning progress and helping that what they learn matches the objectives to be achieved.

\section{Learning Objective Conditions that Require Modules}

According to Robert Heinich, et al (in Majid, 2014), the learning process that involves the activeness of learners is reading $10 \%$, hearing $20 \%$, seeing $30 \%$, seeing and hearing $50 \%$, discussing $70 \%$, experiencing $80 \%$, and teaching others $95 \%$. Thus, the teacher must prepare a good teaching tool to involve the whole sense of the learner in learning especially supporting teaching material. In accordance with the target learning process that can involve affective, cognitive and psychomotor aspects of learning are teaching materials in the form of learning modules.

The benefits of learning to use modules according to Nasution (2010: 206) are 1). Improve the effectiveness of learning because learners can learn anywhere in groups or alone, 2). Determine and set a study time that is more in accordance with the needs and development of students, 3 ). Strictly know the achievement of student competencies gradually through the criteria set out in the module, 4). Knowing the weaknesses or competencies that have not been achieved by students based on the criteria set out in the module so that they can decide and help participants to improve their learning and do remedial. Whereas the purpose of learning to use modules is to reduce the diversity of the learning capacities of students through independent learning activities.

\section{Module Quality}

Module quality can refer to quality according to Nasution (2010: 217) which states that the quality of educational products is the point of view of the development of learning material, but besides that consideration of three aspects of quality namely validity, practicality and effectiveness can be used on a wider product range.

According to Nasution, (2010: 231), validity refers to the level of intervention design based on knowledge of content validity and construct validity. Validity is a measure that shows the validity of an instrument or data. The principle of validity is measurement or observation in collecting data. 


\section{Module Effectiveness}

Module development must pay attention to the characteristics required as an effective module. According to Chomsin S.W. and Jasmadi (2008: 50), the characteristics of a good module are: a). Self Instruction, b). Self Contained, c). Stand Alone (Stand Alone), d). Adaptive, as well as e). Friendly / Familiar (User Friendly)

\section{Module Compilation Procedure}

The module preparation process consists of three main stages. First, determine learning strategies and appropriate learning media. At this stage, it is important to pay attention to the various characteristics of the competencies to be learned, the characteristics of the students, and the characteristics of the context and situation in which the module will be used. Second, produce or realize physical modules. The component contents of the module include the following: learning objectives, required learners' requirements, substance or learning material, forms of learning activities and supporting components. Third, develop assessment tools. In this case, it is necessary to make sure that all aspects of competency (knowledge, skills and related attitudes) can be assessed based on certain criteria that have been set.

So in development research, indicators to state that module implementation is said to be effective can be seen in the components that accompany it. Like the learning outcomes of students and the process of student activity. In this developmental research, the researcher measures the effectiveness of the module from the student's final learning outcomes and the student's activity process using the module.

\section{Module Advantages and Weaknesses}

Modules have advantages as stated by Vembriarto (1981: 25). The advantages of using modules in the teaching and learning process include:

1) Overcoming the limitations of time, space, and senses, both students and teachers.

2) Can be used appropriately and varied, such as to increase motivation or enthusiasm for learning, develop the ability to interact directly with the learning environment.

3) Allows students to be able to measure or evaluate their own learning outcomes.

4) Students are more active in learning.

5) The teacher can act as a guide, not merely as a teacher.

6) Getting students to believe in themselves.

7) There is a healthy competition between students.

8) Can ease the burden on the teacher.
9) Learn more effectively, and evaluate significant improvements.

10) This system can absorb the attention of children so that lessons show are more successful when compared with lectures.

Learning to use modules has many benefits, students can take responsibility for their own learning activities, learning with modules highly values individual differences, so students can learn according to their ability levels, so learning is more effective and efficient.

b). Weaknesses of Module Use

Modules have weaknesses as stated by Vembriarto (1981: 25). Weaknesses of the use of modules in the learning process as stated by Vembriarto include:

1) Difficulties in students cannot be overcome immediately.

2) Not all students can study on their own, but need teacher's help.

3) Not all materials can be modulated and not all teachers know how to implement learning using modules.

4) The difficulty of preparing materials and requires a lot of costs in making modules.

5) There is a tendency for students not to study the module well.

Learning by using modules is also often referred to as independent learning. According to Suparman (1993: 197), states that this form of independent learning activities has the following shortcomings:

1) The cost of developing materials is high and it takes a long time.

2) Determine high learning discipline that students may not have in general and students who are not yet mature in particular.

3) Requires greater perseverance from the facilitator to continuously monitor student learning processes, provide motivation and individual consultation every time the student needs.

Tjipto (1992: 72), also revealed a number of things that burdened learning by using modules, namely:

1) Learning activities require good organization

2) During the learning process several tests / examinations need to be held, which need to be assessed as soon as possible

Based on some of the opinions above, it can be concluded that in learning to use the module also has some fundamental weaknesses, namely that it requires a large 
amount of cost and requires a long time in the procurement or development of the module itself, and requires high persistence from the teacher as a facilitator to continue to monitor student learning process.

\section{The Nature of Integrated Learning}

Integrated Learning or commonly referred to as thematic learning is an approach to learning that deliberately links several aspects both within intra subjects and between subjects. With this integration students will gain full knowledge and skills so that learning becomes meaningful for students. Meaningful here means that in thematic learning students will be able to understand the concepts they learn through direct and real experience that links between concepts in intra subjects and between subjects.

Integrated learning is based on an approach that involves students ranging from planning, exploring, and brainstorming and concluding. With an integrated approach, students are motivated to learn and work in groups and learn from the results of their own experiences. Furthermore, in its implementation children can be invited to participate actively in exploring and elaborating themes, topics or events, students learn the process and content (material) of more than one field of study at the same time. This theme or topic or event development activity is important in developing students' systematic and systematic thinking skills.

Several other integrated / thematic learning definitions were put forward by integrated / thematic learning experts among them:

a. According to Beans (Sa'ud et al: 4) integrated learning is an approach to develop children's abilities in the formation of knowledge based on interactions with the environment and experiences in their lives;

b. According to Jacobs (Sa'ud et al: 5) integrated learning is an approach in learning as a process for linking and integrating teaching material in a subject or between subjects with all aspects of child development, the needs and interests of children, as well as the needs and demands of the environment social family.

c. According to Prabowo (2000: 2), integrated learning is a teaching and learning approach that involves several fields of study. Teaching and learning approaches like this are expected to be able to provide meaningful experiences to students. Meaning here because in the thematic learning it is hoped that children will gain an understanding of the concepts they have learned through direct experience and relate them to other concepts they already understand.
From the above understanding it can be concluded that integrated learning is a teaching and learning approach that pays attention and adapts to the level of development of students (Developmentally Appropriate Practical). In accordance with the stages of student development, ways of student learning, concepts of learning and meaningful learning, learning activities should be carried out using an integrated learning approach. Integrated learning is a learning approach that uses focus or themes to link several subjects so as to provide meaningful experiences to students. Bredekamp in (Developing Appropriate Practice 1987), explains that integrated learning is a learning approach that uses a center of interest in the form of a focus or theme or concept, which serves as a binding force for cohesiveness to form a new concept that is meaningful to a child's life and is relevant to a given concept. The center of interest as the core of the study should be lifted from essential concepts or problems in students' daily lives. This will be very meaningful for student life. Through direct experience and connecting with other concepts that are already owned, students will be able to build their understanding of new concepts in greater depth.

Based on the description above, it can be concluded that the notion of integrated learning is 1) Learning that starts from the existence of a center of interest that is used to understand the symptoms and other concepts, both originating from the field of science itself and from the field of science other; 2) A way to develop students' knowledge and skills simultaneously; and 3) A learning approach.

Integrated learning is very concerned about the needs of children in accordance with their development, namely by actively involving in the learning process both physically and emotionally. For this reason, the activities provided include active searching, exploring, and discovering concepts and principles of science that are holistic, meaningful, and authentic so that students can apply learning outcomes to solve real problems in daily life. The learning process should provide a variety of activities and materials that are diverse and offer choices for students so that they can choose them for small and independent group activities and provide opportunities to take their own initiative, perform skills on their own initiative as the activity they choose.

\section{Excellence and Limitations of Integrated Learning}

Integrated learning has advantages over the conventional approach, which is as follows.

a. The experiences and learning activities of students will always be relevant to the level of child development. 
b. The selected activity can be adjusted to the interests and needs of students.

c. All learning activities are more meaningful for students so that learning outcomes will last longer.

d. Integrated learning fosters students' thinking and social skills.

e. Integrated learning presents activities that are pragmatic with problems that are often encountered in the real life / environment of students.

f. If integrated learning is designed together, it can improve cooperation between teachers in the related field of study, teachers and students, students with students, students / teachers with resource persons; so learning is more fun, learning in real situations, and in more meaningful contexts.

In addition to the above advantages, integrated learning has limitations, especially in its implementation, namely in the design and implementation of evaluation which requires more teachers to evaluate the process, and not only evaluate the impact of direct learning.

Through integrated learning, students can gain direct experience, so they can add strength to receive, save, and apply the concepts they have learned. Thus, students are trained to be able to discover for themselves various concepts that are studied thoroughly (holistically), meaningful, authentic and active. The way the packaging of learning experiences are designed by the teacher is very influential on the meaningful experience for the students. A learning experience that shows the relationship between conceptual elements will make the learning process more effective.

Integrated learning provides opportunities for teachers and students to develop learning that is intact, comprehensive, and meaningful in accordance with the expectations, abilities, and needs of students.

\section{Development Research Procedure}

Four-D or $4 \mathrm{D}$ models can generally be seen as models for instructional development (a model for instructional development). The development of the FourD model is based on instructional development by Twelker, Urbach, and Buck (Thiagarajan, Semmel, and Semmel, 1974) with stages: analysis, design, and evaluation. Initially Thiagarajan, Semmel, and Semmel (1974) modified this model into four stages, namely: analysis, design, evaluation, and dissemination. Furthermore, this design after going through a process of revision and development in the training conducted is called the Four-D model which includes four stages: define, design, develop, and disseminate.
The definition phase (define) includes five phases: (1) initial-end analysis (front-end analysis); (2) learner analysis; (3) task analysis; (4) concept analysis; and (5) specific instructional objectives (specifying instructional objectives). The design phase includes four phases: (1) constructing a constructing criterion-referenced test; (2) media selection (media selection); (3) format selection; and (4) initial design. The development phase includes two phases: (1) expert appraisal; and (2) developmental testing. The dissemination phase includes three phases: (1) validating testing; (2) packaging; and (3) diffusion and adoption. (Rocmad, 2012: 61)

Development of learning media involves a number of steps that must be taken by a developer in learning in order to obtain good learning materials in accordance with the characteristics of students. This is important to do so that the learning process is more effective in its process, time and cost.

In the preparation and development of this media must be done with the right procedures so that it can be clearly identified what must be done. One model of media development that can be selected as a guideline in the preparation of instructional media is the Four-D development model suggested by Thiagarajan, Semmel, and Semmel. The Four-Dmodel media development model suggested by Silvasailam Thiagarajan, Dorothy S. Semmel, and Melvyn I. Semmel uses the Four-D learning system. This model consists of 4 stages of development, namely Define, Design, Develop, and Desseminate or adapted into a 4-P model, namely Defining, Designing, Developing, and Disseminating (Trianto, 2007: 65).

\section{RESEARCH METHODS}

This research was conducted in the Department of Primary School Teacher Education (PGSD) Gorontalo State University. This research was conducted in the even semester of the 2018-2019 school year.

The datacollection technique that will be used to support problem solving are, as follows: a)questionnare, b) interview, c)documentation. The data obtained will be analyzed using descriptive statistical analysis then data that has been analizedquantitatively are deepened or strengthened by result of interview.

\section{RESULT}

A. Objectives of Integrated Learning Objectives in the PGSD Department of Gorontalo State University 
The integrated learning objective conditions in the PGSD majors in Gorontalo State University based on the analysis of the results of observations and interviews are categorized in three forms, namely planning is not in accordance with learning outcomes, the implementation is still carried out without using the learning module, and still uses many learning resources so that it does not focus on learning and assessment.

Pre-research activities theoretically begin with the needs of students, namely by analyzing whether there is a mismatch between the current state of students and the needs of students, and determining learning objectives. The steps taken are conducting discussions with the team teaching integrated learning subjects to discuss the problems that exist in lectures on integrated learning courses. From this team teaching discussion, the author is interested in developing a learning module that is an integrated learning module for students majoring in PGSD UNG. The author has developed an integrated learning module that aims to be used in integrated learning subjects and also aims so that students can study independently and can also learn face to face with their lecturers.

\section{RESEARCH RESULTS AND DISCUSSION}

\section{A. Objectives of Integrated Learning Objectives in the PGSD Department of Gorontalo State University}

The integrated learning objective conditions in the PGSD majors in Gorontalo State University based on the analysis of the results of observations and interviews are categorized in three forms, namely planning is not in accordance with learning outcomes, the implementation is still carried out without using the learning module, and still uses many learning resources so that it does not focus on learning and assessment.

Pre-research activities theoretically begin with the needs of students, namely by analyzing whether there is a mismatch between the current state of students and the needs of students, and determining learning objectives. The steps taken are conducting discussions with the team teaching integrated learning subjects to discuss the problems that exist in lectures on integrated learning courses. From this team teaching discussion, the author is interested in developing a learning module that is an integrated learning module for students majoring in PGSD UNG. The author has developed an integrated learning module that aims to be used in integrated learning subjects and also aims so that students can study independently and can also learn face to face with their lecturers.
The basic principles in developing this learning module are 1). Helping students focus on their learning resources, 2). Helping students prepare for independent learning, 3). Have a learning plan that can be responded to maximally, 4). Contains learning content that is complete and able to provide student learning opportunities, 5). Can monitor student learning activities, and 6). Can provide advice and guidance as well as information on the level of student learning progress.

\section{B. The Quality of Integrated Learning Modules Developed by Students of the Department of PGSD UNG;}

To find out whether the integrated learning modules in the Department of PGSD UNG are qualified or not, an assessment of the material, media and language is carried out by experts. The results of the analysis of the content validity of each item calculated using the Aiken formula, with the number of panelists / validators as many as 7 people and the number of scores for the rating choices on each item are 5 starting from 1 (lowest score) to 5 (highest score), obtained that the validation index all items between $0.54-1.00$ with a "valid" conclusion.

The overall steps of the research to produce quality integrated learning modules have been carried out well. Data on expert assessment of Integrated Learning Modules, based on aspects of content eligibility, aspects of material presentation, which is contained in the Integrated Learning Module instrument.

This integrated learning module already contains the characteristics of a quality module so that the writer believes that this integrated learning module is a quality module.

\section{The Effectiveness of Integrated Learning Modules in the PGSD UNG Department.}

The effectiveness of integrated learning modules is analyzed using the Semester Learning Plan (RPS), Student Activity Sheets (LKM), and Integrated Learning Modules.

For data analysis using descriptive qualitative and quantitative descriptive data analysis. Qualitative data analysis is used to describe the results of preliminary observations before designing the learning module and the results of the preparation of the learning module and describe the suggestions that have been given by the validators, expert lecturers to perfect the learning module that has been made. Whereas for quantitative data analysis it is used in idealized research and the level of feasibility of the learning modules assessed by expert lecturer validators. The results of the small group test and field trial use the 
tabulation of respondent results in the form of a percentage.

\section{DISCUSSION}

Integrated Learning Module with the 4D Model

The 4-D (Define, Design, Develop and Desseminate) development research conducted by researchers has clear, systematic and directed steps making it easier for researchers to develop integrated learning modules. The 4D development model consists of define, design, develop while the researchers disseminate stages are limited to the UNG campus environment due to time and cost considerations.

The learning module validator on integrated learning materials consists of several experts, namely lecturers, and experts (media, content and so on). After the learning module has been validated, a revision is made. From the results of the revision of the validator's study then a small group trial was conducted. Furthermore, the results of the small group trial were revised again and then tested on a field trial of 40 PGSD UNG students. In addition, it is not denied to assess the feasibility of the learning tools of the participation of lecturers and students of PGSD UNG also needed.

\section{CONCLUTION}

The conclution showed that, the learning modules that have been designed by researchers and validated by experts obtained the results in the form of valid and reliable learning modules with conclusions very feasible to use. The results of the validation carried out by the experts in the form of suggestions or input accompanied by an assessment of each module. Expert advice or panelists are processed statistically to be the basis for making decisions whether the module is valid and reliable.

Based on the conclution above, the following implications are: 1. Learning using Integrated learning modules in students majoring in PGSD can be applied to other learning. 2. Learning by using an Integrated learning module in PGSD majors students can improve the learning abilities of PGSD majors students. 3. Integrated Learning Modules can be used as an alternative to the development of other course learning modules.4. The Integrated Learning Module needs to be a concern for lecturers for the better achievement of student learning abilities.

New innovations are needed in the world of education, especially education, because it does not rule out the development of research that has been done by researchers will emerge similar research even better from various aspects to improve the quality of education.

\section{REFERENCES}

[1] Aisyah Siti. 2007. Modul Pembelajaran Terpadu. Jakarta: Universitas Terbuka

[2] Aminuddin, 1994. Pembelajaran Terpadu sebagai Bentuk Penerapan Kurikulum 1994 Mata pelajaran Bahasa Indonesia. Makalah dalam Seminar JPBSI IKIP Malang, 26 November 1994.

[3] Balsamo Kathy. 1994. Thematic Activities for Student Portfolios. Beavercreek: Pieces of learning.

[4] Bredekamp. 1987. Development Appropiate Practice. New York : National Association for the Education of Young Children (NAEYC)

[5] Chomsin S. Widodo, Jasmadi, 2008 PanduanMenyusunBahan Ajar Berbasis Kompetensi. Jakarta: PT Elek Media KOmputindo.

[6] Clearly Pauline, Luca, Di. 1986. Learning Through an Approaches and Guildelines Integrated Curriculum. Victoria :Ministery of Education.

[7] Collins Gillian, Dixen Hazel, 2001. Integrated Learning: Planning Curriculum Unit. Bookshelf Stage 3.Australia : Bookshelf Publishing

[8] Dale, Edgar, 1969. Audio Visual Methods in Teaching, New Yorg: Holt, Rinehart and Winston Inc. The Dryden Press.

[9] Depdiknas. 2008. Panduan Pengembangan Bahan Ajar. Retrieved from 25 Februari 2019 Pukul 15.00 WIBTA.http://dc218.4shared.com/download/vj4M9K10/5_P ENGEMBANGAN_BAHAN_AJAR .rar?tsid=201200227061731-a8f2e27

[10] Depdiknas.1996. PembelajaranTerpadu D-II PGSD Dan S-2 Pendidikan Dasar. Jakarta: Depdiknas.

[11] Fajar, Setia. 2012. Pemetaan Pembelajaran Tematik. Retrieved from Oktober 19, 2012, http://fajarsetia2020.blogspot.com/2012/10/perancanganpembelajaran-terpadu.html

[12] Fogarty, Robin. 1991. How to Integrated the Curricula. Palatine, Ilinois: IRI/ Skylight Publishing, Inc.

[13] Hamalik, O, 1994. Media Pendidikan, cetakan ke-7. Bandung: Penerbit PT. Citra Aditya Bakti.

[14] Hamid, Hamdani. 2013. Pengembangan Sistem Pendidikan di Indonesia. Bandung: Pustaka Setia.

[15] Heinich, Robert dkk. 1982. Instructional Media and The Technologies of Instruction. New York: John Wiley \& Sons

[16] Indrawati. 2009. Modul Pembelajaran Terpadu Di Sekolah Dasar. Jakarta: Pusat Pengembangan dan Pemberdayaan Pendidik dan Tenaga Kependidikan Ilmu Pengetahuan Alam (PPPPTK IPA).

[17] Iswamine. 2010. Pemetan Tema. Retrieved from Juni 3, 2010, http://iswamine.blogspot.com/2010/06/pemetaantema.html

[18] Kemdikbud, 2017. Panduan Penilaian oleh Pendidik dan Satuan Pendidikan SMP. Jakarta: Pusat Pengembangan Tenaga Kependidikan BPSDMPPMP. 
[19] Kurniasih, Imasdan berlin Sani.2016. Ragam Pengembangan Modul Pembelajaran Untuk Peningkatan Profesionalitas Guru. Kata Pena.

[20] Majid, Abdul. 2014. Pembelajaran Tematik Terpadu. Bandung: PT. Remaja Rosdakarya.

[21] Marzano, Robert J. 1992. Dimensions of Thinking: A Framework for Curricullum and Instruction.ASCD. Alexandria:125 New Street.

[22] Mathews, Louis De Vriesdan Jean Crawford. 1989. Learning through an Integrated Curruculum: Approach abd Guidelines. Victoria: Ministry of Education.

[23] Meidul. 2012. Pemetaan Pembelajaran Tematik. Retrieved from April 12, 2012, http://meidulniez.blogspot.com/2012/04/pemetaan-pembelajarantematik.html

[24] Mukminan, 2008. Pengembangan Media Pembelajaran. Universitas Negeri Yogyakarta.

[25] Mulyasa, E. 2015.Pengembangan dan Implementasi Kurikulum 2013. Bandung: PT. Remaja Rosdakarya.

[26] Pusat Kurikulum.2002. Penjelasan Umum Kurikulum Berbasis Kompetensi. Jakarta: DEPDIKNAS.

[27] Ratumanan, T.G danRosmiatilmas. 2019. Perencanaan Pembelajaran. Jakarta: PT. Raja grafindo Persada.

[28] Reksoatmodjo, TedjoNarsoyo. 2010. Pengembangan Kurikulum Pendidikan Teknologi dan Kejuruan. Bandung: PT. Refika Aditama.

[29] Resmini Novi dkk. 2009. Pembelajaran Terpadu di SD. Jakarta: UNIVERSITAS TERBUKA

[30] Resmini, Novi, dkk. 1996. Penentuan Unit Tema dalam Pembelajaran Terpadu. Malang: IKIP Malang.

[31] Rudy. 2011. Perencanaan Pembelajaran Terpadu. Retrieved from Januari 1, 2011, http://rudyunesa.blogspot.com/2011/01/perencanan-pembelajaranterpadu.html

[32] Sukiman, 2015. Pengembangan Kurikulum Perguruan Tinggi. Bandung: Rosda Karya

[33] Sukmadinata, N.S. 2000. Pengembangan Kurikulum - Teori dan Praktik. Bandung: Rosda Karya

[34] Thiagaraja, S, Semmel D.S. \& Sammel, M.J Sivasailam. 1974. Instructional Development For Training Teacher of Exceptional Children a Sourcebook. Minnepoli. Indiana University

[35] Tim Pengembang PGSD. 1997. PembelajaranTerpadu D-II dan S-II Pendidikan Dasar.Jakarrta: Dirjen Dikti, Bagian Proyek Pengembangan Pendidikan Guru Sekelah Dasar.

[36] Trianto. 2007. Modul Pembelajaran Terpadu Dalam Teori Dan Praktek. Jakarta: prestasi pustaka publisher

[37] Udin SyaefuddinSa'ud, Ph.Ddkk. 2006. Pembelajaran Terpadu. Bandung: UPI PRESS

[38] Wilson Lorraine, Malmgren David, RamageShirl. 1991. An Integrated Approach Learning, Melbourne : Thomas Nelson Australia 